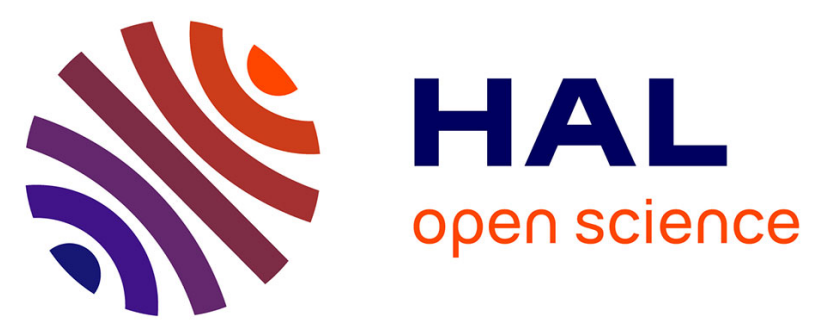

\title{
P-Chirogenic Triazole-Based Phosphine: Synthesis, Coordination Chemistry, and Asymmetric Catalysis
}

Jérôme Bayardon, Benjamin Rousselle, Yoann Rousselin, Quentin Bonnin, Raluca Malacea-Kabbara

\section{- To cite this version:}

Jérôme Bayardon, Benjamin Rousselle, Yoann Rousselin, Quentin Bonnin, Raluca Malacea-Kabbara. P-Chirogenic Triazole-Based Phosphine: Synthesis, Coordination Chemistry, and Asymmetric Catalysis. European Journal of Organic Chemistry, 2020, 2020, pp.4723-4729. 10.1002/ejoc.202000723 . hal-02992577

\section{HAL Id: hal-02992577 \\ https://hal.science/hal-02992577}

Submitted on 18 Nov 2020

HAL is a multi-disciplinary open access archive for the deposit and dissemination of scientific research documents, whether they are published or not. The documents may come from teaching and research institutions in France or abroad, or from public or private research centers.
L'archive ouverte pluridisciplinaire HAL, est destinée au dépôt et à la diffusion de documents scientifiques de niveau recherche, publiés ou non, émanant des établissements d'enseignement et de recherche français ou étrangers, des laboratoires publics ou privés. 


\section{P-chirogenic triazole-based phosphine: synthesis, coordination chemistry and asymmetric catalysis}

Jérôme Bayardon, *a] Benjamin Rousselle,[a] Yoann Rousselin,[a] Quentin Bonnin,[a] and Raluca Malacea-Kabbara*[a]

Abstract: Herein we report the synthesis of a new P-chirogenic triazole-based phosphine according to the ephedrine methodology. Upon reaction with late transition-metal derivatives, $\operatorname{Rh}(\mathrm{I})$ and $\operatorname{Pd}(\mathrm{II})$, phosphine-triazole forms complexes with bidentate $P, N$ coordination, as demonstrated by spectroscopic and X-ray crystallographic analyses. First experiments in asymmetric catalysis showed the catalytic potential of this new chiral $P, N$-type ligand.

\section{Introduction}

1,2,3-triazole-based phosphines are new class of compounds which have found many applications, especially in coordination chemistry as well as in catalysis[1]. The phosphine moiety can be incorporated either directly on the triazole ring such as in compounds 1-3 (Figure 1) or into the fragments attached to the nitrogen ring as for 4-6 (Figure 1). As examples in the first case, Zhang developed ca. 10 phosphine ligands 1 named "Clickphos" on a 1,2,3-triazole backbone for Pd-catalyzed amination or Suzuki-Miyaura coupling reaction[2]. In parallel, extensions of their synthesis and luminescent properties were studied by Bräse and co-workers[3]. Diphosphines supported by bis(triazole) backbone 2 were recently synthesized by Manoury and Virieux in order to study their coordination chemistry toward transition metals[4]. Chiral planar triazolylphosphines were also synthesized using click-chemistry such as Clickferrophos 3 which was able to induce high enantioselectivities in asymmetric rhodium- and ruthenium-catalyzed hydrogenation of alkenes or ketones as well as in copper-catalyzed synthesis of pyrrolidines[5]. In the second case, different linkers were used to attach phosphine moiety to the triazole unit. Alkyl ligating groups such as methylene or ethylene were employed, respectively for the synthesis of bis-phosphinotriazoles 4 used in the preparation of PCP pincer complexes, and the modular synthesis of more than twenty P-chirogenic BH3-protected monophosphines 5, as described by Gandelman[6] and Kann[7]. On the other hand, mono- and diphosphines such as 6-7 bearing phosphino group on the aromatic ring linked to the triazole backbone were also synthesized by Balakrishna[8] for their studies in coordination chemistry with various transition metals.

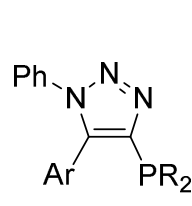

1<smiles></smiles>

2

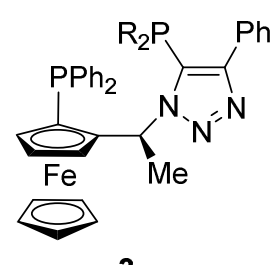

3

"Clickphos" (Manoury and Virieux) "ClickFerrophos"<smiles>[R20]Cc1cn(C[R20])nn1</smiles>

(Gandelman)

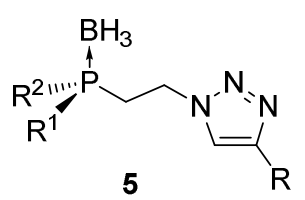

(Kann)<smiles>c1ccc(-c2cn(-c3ccccc3)nn2)cc1</smiles>

6 (Balakrishna)

Figure 1. Examples of 1,2,3-triazole-based phosphines. 
The triazole itself has already shown its good metal-coordination properties[9] but surprisingly, the use of triazoles as nitrogen donors in $\mathrm{P}, \mathrm{N}$ ligands has been only few described to date[1g, $1 \mathrm{n}-0,8]$. Moreover, chiral $\mathrm{P}, \mathrm{N}$ ligands containing a triazole backbone and their coordination chemistry have, as far as we know, not been reported yet [10].

As a part of our ongoing research concerned with the stereoselective synthesis of P-chirogenic orthofunctionalized arylphosphine and their application in asymmetric catalysis[11], we will report herein the preparation of a P-chirogenic 1,2,3-triazole-based phosphine, in which the nitrogen ring is located in ortho-position of the phosphorus center (Figure 2), its coordination chemistry toward transition metal, $\mathrm{Rh}(\mathrm{I})$ and $\mathrm{Pd}(\mathrm{II})$, and some preliminary results in $\mathrm{Rh}$ - and $\mathrm{Pd}$-catalyzed asymmetric reactions.

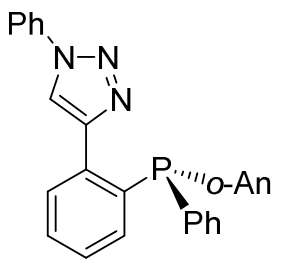

\section{8}

Figure 2. P-chirogenic phosphine 8.

Results and Discussion

The new P-chirogenic 1,2,3-triazole-based phosphine 8 has been synthesized according to ephedrine methodology starting from (+)-oxazaphospholidine borane complex 9, prepared from (-)ephedrine[12], as illustrated in Scheme 1.

The reaction of the complex (+)-9 with o-anisyllithium[13] stereospecifically affords the aminophosphine-borane 10 in 90\% yield, by a ring opening reaction upon P-O bond cleavage. After acidolysis of the aminophosphine-borane 10 with dry $\mathrm{HCl}[14]$, the resulting chlorophosphine-borane 11 reacted with 2-[2-(trimethylsilyl)ethynyl]phenyllithium[15] to provide the corresponding Pchirogenic phosphine-borane 12 in moderate yield because of the partial decomplexation of the borane due to the high steric hindrance around the phosphorus center[16]. To prevent this, the phosphine borane 12 is immediately transformed to phosphine-sulfide 13 by a tandem decomplexation-sulfidation reaction in presence of DABCO and elementary sulfur. The phosphinesulfide 13 is obtained in $80 \%$ overall yield from 10 and its analysis by HPLC on chiral column ( $99 \%$ ee), proves that the two-step reaction sequence proceeds without racemization at the P-center. The desilylation of 13 was readily achieved at room temperature using $\mathrm{K} 2 \mathrm{CO} 3$ in methanol/THF. The resulting terminal alkyne 14 was isolated in $97 \%$ yield after silica gel chromatography. It was then subjected to the $\mathrm{Cu}(\mathrm{I})$-catalyzed cycloaddition with phenyl azide under classical Click reaction conditions (CuSO4.5H2O (10 mol\%)/sodium ascorbate (20 mol\%) in t-BuOH-H2O (1:1))[17] to form the corresponding triazolylphosphine-sulfide 15 in $62 \%$ yield. Finally, desulfidation of 15 was performed by reaction with $\mathrm{Si} 2 \mathrm{Cl} 6[18]$ in toluene at $80^{\circ} \mathrm{C}$ during one hour to give, after recrystallization, $\mathrm{P}$ chirogenic phosphine 8 in $83 \%$ yield (Scheme 1). The enantiomeric excess of phosphine-triazole 8 was determined by HPLC on a chiral column with $99 \%$ ee. Moreover, crystals of 8 suitable for X-ray analysis have been obtained and the X-ray structure is depicted in Figure 3 . The compound 8 crystallizes in P212121 chiral space group and the Flack parameter refinement allows the unambiguous determination of the R-absolute configuration at the phosphorus atom.[19] 


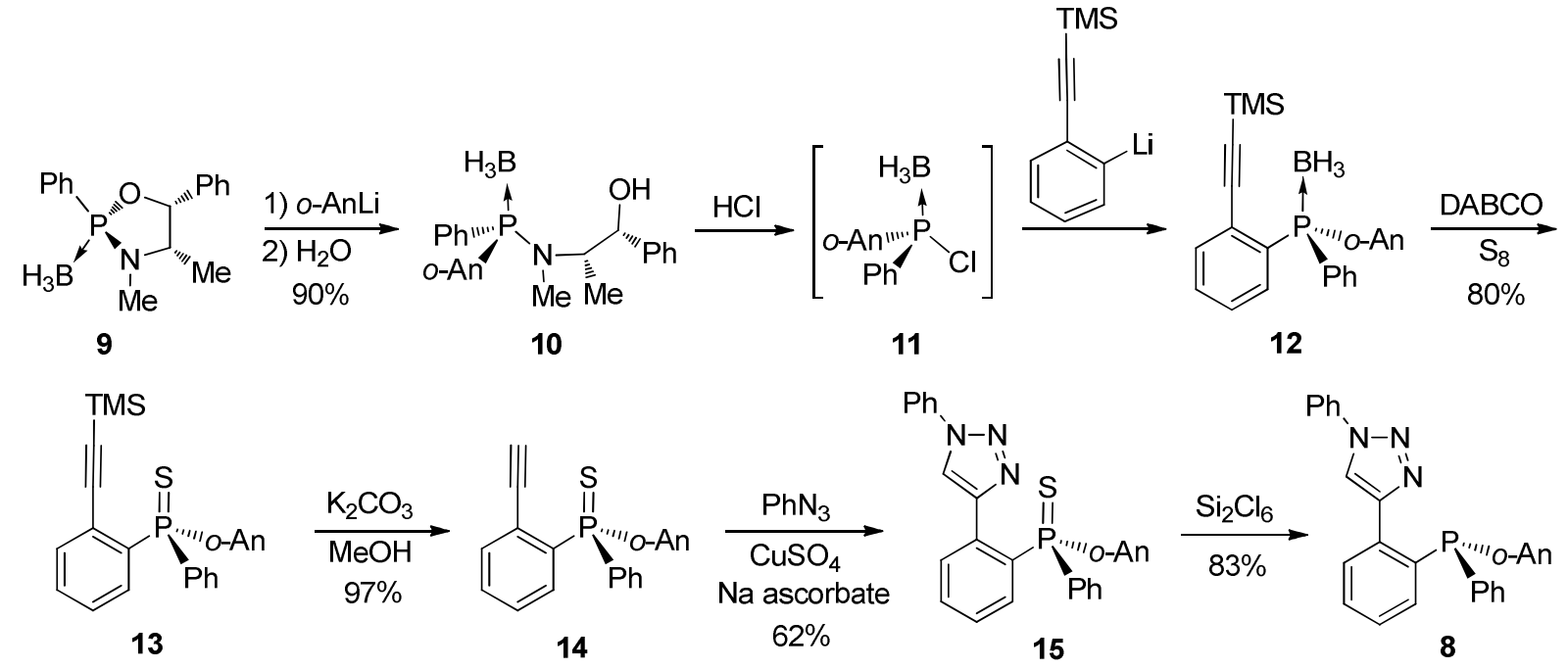

Scheme 1. Synthetic route to P-chirogenic phosphine-triazole 8.

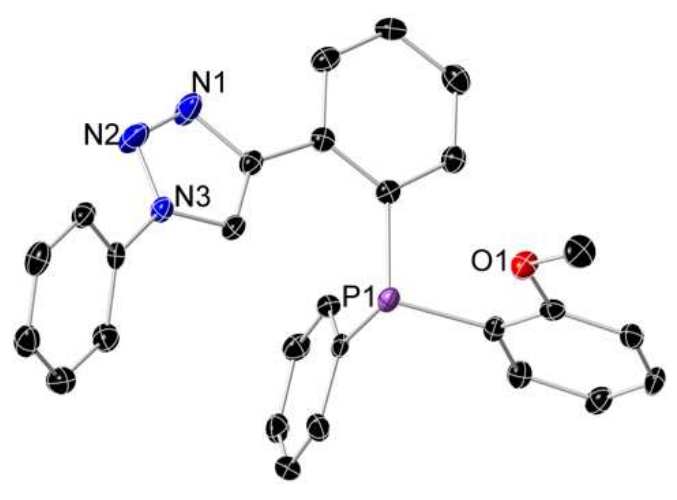

Figure 3. View of phosphine-triazole 8 . Thermal ellipsoids are drawn at $50 \%$ probability plot. Hydrogen atoms were omitted for clarity.

With new triazole-phosphine-containing $\mathrm{P}, \mathrm{N}$ ligand in hands, we examined the complexation with $\mathrm{Pd}(\mathrm{II})$ and $\mathrm{Rh}(\mathrm{I})$ salts (Scheme 2). Phosphine 8 reacted with half equivalent of $[\mathrm{Pd}(\mathrm{n} 3-\mathrm{C} 3 \mathrm{H} 5) \mathrm{Cl}] 2$ and AgPF6 in $\mathrm{CH} 2 \mathrm{Cl} 2 / \mathrm{MeOH}$ at room temperature to give the corresponding cationic palladium-allylic complex 16 in 68\% yield. Spectroscopic and X-ray crystallographic analyses (vide infra) have elucidated that the phosphine-triazole subunit in 16 coordinates to the palladium(II) center as the P,N-bidentate ligand. 


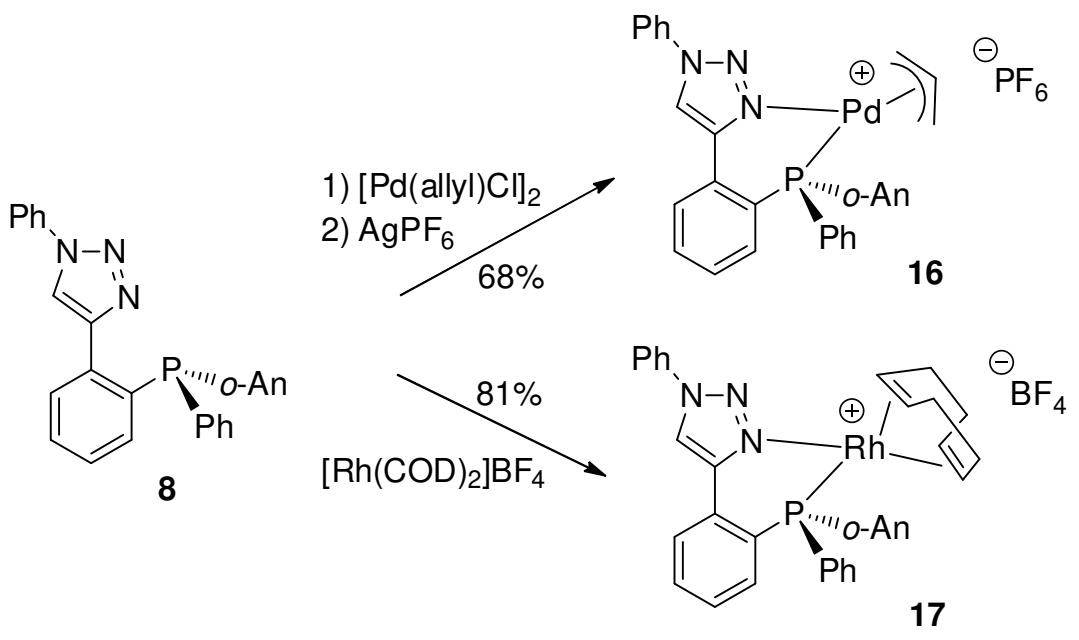

Scheme 2. Synthesis of $\mathrm{Pd}(\mathrm{II})$ and $\mathrm{Rh}(\mathrm{I})$ complexes with P-chirogenic phosphine-triazole 7.

In 31P $\{1 \mathrm{H}\}$ NMR spectroscopy, a clear shift of the phosphine signal with respect to the free ligand was observed (from -22.4 ppm for 8 to $11.4 \mathrm{ppm}$ for 16). The $1 \mathrm{H}$ NMR signal of the triazole proton is shifted $0.63 \mathrm{ppm}$ to lower field (from 8.19 to $8.82 \mathrm{ppm}$ )[20]. In addition, 15N NMR spectroscopy of phosphinetriazole 8 and $\mathrm{Pd}(\mathrm{II})$-complex 16 was recorded using $1 \mathrm{H}-15 \mathrm{~N} \mathrm{HMBC}$ correlation experiment (Table 1 ). For the phosphine-triazole 8, the $15 \mathrm{~N}$ NMR chemical shifts are -25 and $-126 \mathrm{ppm}$ for $\mathrm{N}-1$ and N-3 atom respectively[21] (entry 1). In the case of the Pd(II)-complex 16, a large upfield shift (-77 ppm) of N-1 atom was observed (entry 2), attesting the binding of the triazole ring to the metal center[22].

Single crystals of $\mathrm{Pd}(\mathrm{II})$-complex 16 suitable for $\mathrm{X}$-ray diffraction analysis were obtained by recrystallization in $\mathrm{CH} 2 \mathrm{Cl} 2 / \mathrm{MeOH}$. The structure of the complex 16 is shown in Figure 4.

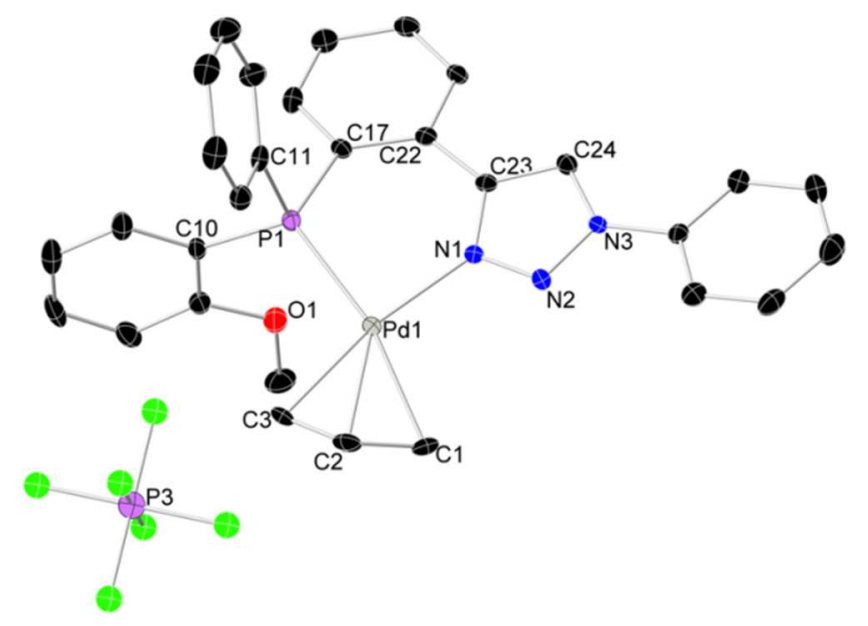

Figure 4. View of complex 16 . Thermal ellipsoids are drawn at $50 \%$ probability plot. Hydrogen atoms, disordered part and other complex presents in asymetric unit are omitted for clarity.

The compound 16 crystallizes with two complexes in asymmetric unit. "endo/exo" isomers of 16 can be defined when the central C-atom of the allyl group points in opposite direction or toward the oanisyl substituent. In one of them, the allyl ligand was found to be disordered and was refined with the 
central C-atom in two positions. Refining the occupancy factors afforded an "endo/exo" ratio of 50\%. The other complex is the "endo" form as depicted in Figure 4.

This structure confirms that ligand 8 binds palladium through phosphorus and nitrogen atoms to form a six-membered ring chelate. The conformations of the six-membered rings of the bound ligand were assessed by ring-puckering analysis [23] $\left(Q=0.407\right.$, 国] $=120^{\circ}$ [ $=215^{\circ}$ for $P d 1$ complex, $Q=0.589$, 国] = $66.8^{\circ}$ ] $=49^{\circ}$ for $\mathrm{Pd} 1 \mathrm{~A}$ complex), and reveal a half-boat conformation where the phosphorus atom is farthest from the mean plane of six-membered ring (P1 = $0.257 \AA$ from Pd1, N1, C23 ,C22 ,C17 , P1 mean plane and $\mathrm{P} 1 \mathrm{~A}=0.378 \AA$ from $\mathrm{Pd} 1 \mathrm{~A}, \mathrm{~N} 1 \mathrm{~A}, \mathrm{C} 23 \mathrm{~A}, \mathrm{C} 22 \mathrm{~A}, \mathrm{C} 17 \mathrm{~A}, \mathrm{P} 1 \mathrm{~A}$ mean plane). Both complexes have a sinister conformation of phosphorus atom, but differ by the different orientation of the o-anisyl group as shown the superposition in Figure 5.

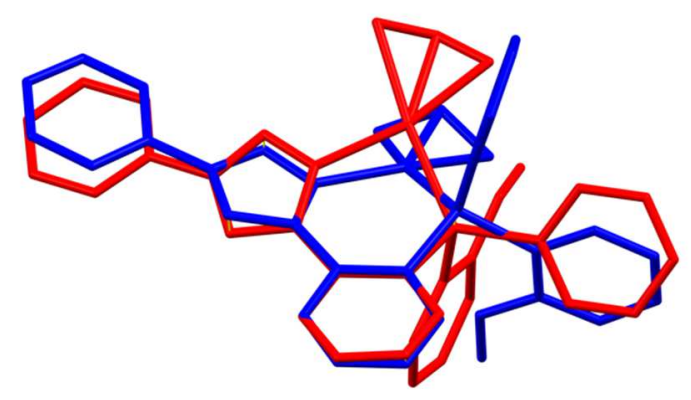

Figure 5. Superposition of both Pd coordination complex present in asymmetric unit.

The coordination geometry is pseudo square-planar. The four coordination sites are occupied by the $\mathrm{P}$ - and $\mathrm{N}$-atom of the phosphine-triazole ligand and the allylic termini. Bond lengths and bond angles are within the expected range for [ $\mathrm{Pd}($ [?3-allyl)] complexes with a soft and a hard donor atom[24].

Table 1. 15N NMR chemical shift in ppm[a] for the compound 8, 16 and 17[b], [c].

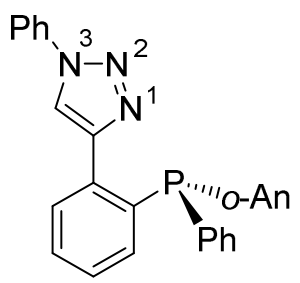

8<smiles>C=C[Pb](C=C)(C(=O)O)c1ccccc1</smiles>

16

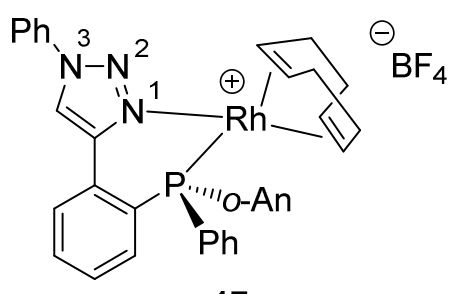

17

Entry Compound $\quad \delta \mathrm{N}-1 \quad \delta \mathrm{N}-2 \quad \delta \mathrm{N}-3$

$\begin{array}{lllll}1 & 8 & -25 & -[d] & -126\end{array}$

$2 \quad 16 \quad-102-[d] \quad-122$

$\begin{array}{lllll}3 & 17 & -106 & -[d] & -123\end{array}$

[a] Referenced to neat $\mathrm{CH} 3 \mathrm{NO} 2$. [b] N-1, N-2 and N-3 for compounds 8, 16 and 17represented above. [c] In $\mathrm{CD} 2 \mathrm{Cl}$ 2. [d] not determined. 
Rhodium complex 17 was also synthesized in $81 \%$ yield by mixing phosphine-triazole 8 and [Rh(COD)2]BF4 in $\mathrm{CH} 2 \mathrm{Cl} 2$ at room temperature (Scheme 2). Analysis of this complex by 31P- $\{1 \mathrm{H}\} \mathrm{NMR}$ spectroscopy shows the presence of a doublet at $\delta 23.4 \mathrm{ppm}$ (1JRh-P $148.7 \mathrm{~Hz}$ ).[25] As previously observed for Pd-complex 16, the $1 \mathrm{H}$ NMR peak of the triazole proton is clearly shifted (from $8.19 \mathrm{ppm}$ for 8 to $8.69 \mathrm{ppm}$ for 17) and 15N NMR indicates also a shift of ca. $-81 \mathrm{ppm}$ toward lower frequency for $\mathrm{N}-1$ atom (from -25 ppm for 8 to -106 ppm for 17 ; table 1 , entries 1 and 3). These data all point to the formation of a rhodium-complex in which the phosphine-triazole 8 shows bidentate $P, N$ coordination.

In the next step, we evaluated the catalytic performance of the new P-chirogenic phosphine-triazole 8 as chiral ligand in asymmetric catalysis. The Rh-catalyzed asymmetric hydrogenation of methyl $\alpha$ acetamidocinnamate 18 and Pd-catalyzed asymmetric allylic alkylation of (E)-1,3-diphenylprop-2-en1 -yl acetate 20 served as test reactions[26] (Scheme 3).

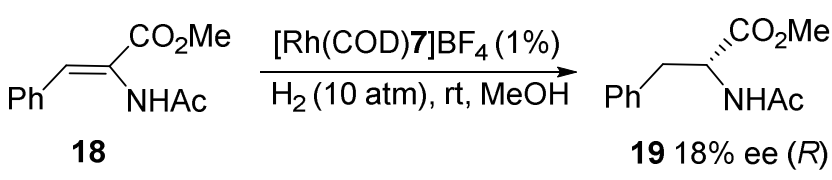

$\overbrace{20}^{\mathrm{PAC}} \frac{\mathrm{Pd}(\mathrm{allyl}) \mathrm{Cl}]_{2}(2 \%) / 7(4 \%)}{\substack{\text { Toluene, rt } \\ \mathrm{CH}_{2}\left(\mathrm{CO}_{2} \mathrm{Me}\right)_{2}, \mathrm{BSA}, \mathrm{KOAC}}}$ (a)<smiles>COC(=O)C(/C=C/c1ccccc1)C(C(=O)OC)c1ccccc1</smiles>

Scheme 3. Asymmetric transition-metal-catalyzed reactions studied using P-chirogenic phosphinetriazole 8.

Hydrogenation of methyl $\alpha$-acetamidocinnamate 18 was carried out using $1 \mathrm{~mol} \%$ of [Rh(COD)8]BF4 in methanol at room temperature during 18 hours under hydrogen (10 bar). In these conditions, hydrogenated product 19 was obtained in full conversion and with low enantioselectivity (18\% ee) (Scheme 3a).

Pd-catalyzed asymmetric allylic alkylation of (E)-1,3-diphenylprop-2-en-1-yl acetate 20 was carried out at room temperature for $5 \mathrm{~h}$ in toluene using $2 \mathrm{~mol} \%$ of $[\mathrm{Pd}(\eta 3-\mathrm{C} 3 \mathrm{H} 5) \mathrm{Cl}] 2$ and $4 \mathrm{~mol} \%$ of ligand 8 in the presence of $\mathrm{N}, \mathrm{O}$-bis(trimethylsilyl)acetamide (BSA) and a catalytic amount of potassium acetate as bases. The complex with 8 gave the product 21 in full conversion with $84 \%$ ee (Scheme $3 \mathrm{~b}$ ).

\section{Conclusions}

New P-chirogenic triazole-based phosphine could be stereoselectively synthezised by using ephedrine methodology and Click-type chemistry. The ability of this phosphine to coordinate with metal centers was also studied and a $\mathrm{Rh}(\mathrm{I})$ complex and a Pd(II) complex could be synthezised. Spectroscopic and Xray crystallographic analyses have elucidated the structures of both complexes in which phosphinetriazole shows bidentate $\mathrm{P}, \mathrm{N}$ coordination. Preliminary studies in asymmetric catalysis have demonstrated the usefulness of this ligand, especially in Pd-catalyzed asymmetric allylic alkylation for which ee up to $84 \%$ was achieved. The synthesis of further P-chirogenic phosphine-triazoles such as 8 and their application as ligand in different asymmetric transformations is under investigation. 


\section{Experimental Section}

General: All reactions were carried out using standard Schlenk techniques under an inert gas. Solvents were dried using a MBRAUN SPS 800. Methylene chloride, diethyl ether, ethyl acetate, pentane, petroleum ether, tetrahydrofuran (THF), toluene and methanol were purchased in anhydrous form. Hexane and 2-propanol for HPLC were of chromatographic grade and used without purification. The reagents 2-[2-(trimethylsilyl)ethynyl]-bromobenzene, n-BuLi (2.5 $\mathrm{M}$ in hexane), DABCO, sulfur, potassium carbonate, $t$-butanol, sodium ascorbate, copper sulfate pentahydrate, hexachlorodisilane, allylpalladium(II) chloride dimer and bis(1,5-cyclooctadiene)rhodium(I) tetrafluoroborate were purchased from commercial suppliers. (2R,4S,5R)-(+)-2,4-dimethyl-2,5-diphenyl-1,3,2oxazaphospholidine-2-borane 9 and (Sp)-(-)-N-methyl-N-[(1R,2S)(1-hydroxy-2-methyl-1-phenyl-2propyl)]amino-o-anisylphenyl-phosphine-borane 10 were prepared according to published procedure[14, 27]. Phenyl azide was prepared from aniline according to procedure described by Mangione et al.[28]. Flash chromatography was carried out with the indicated solvents using silica gel

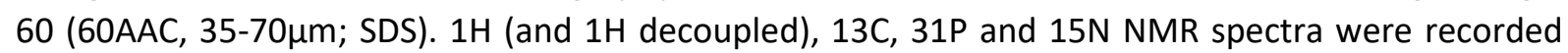
with Bruker 600 Avance III-HD or Bruker 500 Avance III spectrometers at $25^{\circ} \mathrm{C}$, using tetramethylsilane as internal reference for $1 \mathrm{H}$ and $13 \mathrm{C}$ spectra, $85 \%$ phosphoric acid as external reference for 31P NMR and a neat solution of nitromethane as external reference for $15 \mathrm{~N}$ NMR. Sweep width for spectra recorded at $600 \mathrm{MHz}$ were 20,240, 396 and $13-400 \mathrm{ppm}$ for $1 \mathrm{H}, 13 \mathrm{C}, 31 \mathrm{P}$ and $15 \mathrm{~N}$ NMR respectively and for spectra recorded at $500 \mathrm{MHz} 20,237$ and $405 \mathrm{ppm}$ for $1 \mathrm{H}, 13 \mathrm{C}, 31 \mathrm{P}$ NMR respectively. The signals of $13 C$ NMR spectra were allocated by the J-mod technology. Data are reported in ppm as follows: multiplicity ( $\mathrm{s}=$ singlet, $\mathrm{d}=$ doublet, $\mathrm{t}=$ triplet, $\mathrm{q}=$ quartet, $\mathrm{m}=$ multiplet, $\mathrm{br} . \mathrm{s}=$ broad signal), coupling constant(s), integration. HPLC analyses were performed on a Shimadzu chromatograph equipped with a UV detector at $\lambda=210$ and $254 \mathrm{~nm}$. Mass spectrometry and accurate mass measurements (HRMS) were recorded on a Thermo LTQ Orbitrap XL ESI-MS (ElectroSpray lonization Mass Spectrometry). Melting points were measured with a Kofler melting points apparatus and are uncorrected. Optical rotation values were measured at $20^{\circ} \mathrm{C}$ with a Perkin-Elmer 241 polarimeter at $589 \mathrm{~nm}$ (sodium lamp). Elemental analyses were measured with a precision superior to $0.4 \%$ on a CHNS/-O Thermo Electron Flash EA 1112 Series instrument apparatus.

X-Ray experimental procedure: All experimental data procedure and refinement are detailed in Supplementary Information. Data CCDC-1953272 and 1953273 contain the supplementary crystallographic data for this paper. These data can be obtained free of charge from The Cambridge Crystallographic Data Centre via www.ccdc.cam.ac.uk/data_request/cif

(Sp)-o-Anisyl-phenyl-\{2-[2-(trimethylsilyl)ethynyl]phenyl\}phosphine-sulfide (13): A freshly titrated toluene solution of dry $\mathrm{HCl}(40 \mathrm{~mL}, 12 \mathrm{mmol})$ was added to (Sp)-(-)-N-methyl-N-[(1R,2S)(1-hydroxy-2methyl-1-phenyl-2-propyl)]amino-o-anisylphenylphosphine-borane $10(0.786 \mathrm{~g}, 2 \mathrm{mmol})$ and the reaction was stirred under argon at room temperature during two hours. The ephedrine hydrochloride was filtered off using a Millipore $4 \mu \mathrm{m}$ filter. The resulting solution of o-anisyl-chloro-phenylphosphineborane 11 was collected and cooled to $-78^{\circ} \mathrm{C}$. Under argon, 2-[2-(trimethylsilyl)ethynyl]phenyllithium $(4 \mathrm{mmol})$, previously prepared by reaction between 2-[2-(trimethylsilyl)ethynyl]-bromobenzene (1.01 $\mathrm{g}, 4 \mathrm{mmol})$ and $\mathrm{n}$-BuLi $\left(2.5 \mathrm{M}\right.$ in hexane) $(1.8 \mathrm{~mL}, 4.4 \mathrm{mmol})$ in THF $(5 \mathrm{~mL})$ at $-78^{\circ} \mathrm{C}$ during one hour, was added and the resulting mixture was stirred until room temperature during 5 hours. After hydrolysis with water $(20 \mathrm{~mL})$, the mixture was extracted with methylene chloride $(3 \times 20 \mathrm{~mL})$ and the combined organic phases were dried over MgSO4. The solvent was removed under vacuum and the resulting crude product was purified by column chromatography on silica gel using petroleum ether/ethyl acetate $3: 1$ as eluent. The corresponding phosphine borane 12 , obtained partially decomplexed was dissolved under argon in dry toluene $(10 \mathrm{~mL})$ and DABCO $(0.450 \mathrm{~g}, 4 \mathrm{mmol})$ and sulfur $(0.128 \mathrm{~g}, 4 \mathrm{mmol})$ 
were successively added. The reaction mixture was stirred at $50^{\circ} \mathrm{C}$ during 3 hours and the solvent was evaporated. The crude product was purified by column chromatography on silica gel using petroleum ether/ethyl acetate $3: 1$ as eluent to give compound 13 as a white solid $(0.673 \mathrm{~g}, 80 \%)$. Rf 0.44 (petroleum ether/ethyl acetate 3:1); m.p. $50-52^{\circ} \mathrm{C}$ (dec.); Enantiomeric excess: $99 \%$ by HPLC analysis (Chiralpak IA, 1 mL.min-1, hexane/2-propanol 90:10, tR (R) $6.9 \mathrm{~min}$, tR (S) $9.4 \mathrm{~min}$ ); [ $\alpha$ ]D -48.3 (c 0.5, CHCl3). 1H NMR (600 MHz, CD2Cl2): $\delta 0.01(\mathrm{~s}, 9 \mathrm{H}), 3.52(\mathrm{~s}, 3 \mathrm{H}), 6.95(\mathrm{dd}, \mathrm{J}=5.3,8.0 \mathrm{~Hz}, 1 \mathrm{H}), 7.16-7.19$ $(\mathrm{m}, 1 \mathrm{H}), 7.35-7.38(\mathrm{~m}, 1 \mathrm{H}), 7.44-7.61(\mathrm{~m}, 7 \mathrm{H}), 8.02-8.05(\mathrm{~m}, 2 \mathrm{H}), 8.17$ (ddd, J = 2.0, 8.0, $16.7 \mathrm{~Hz}, 1 \mathrm{H})$; $\{1 \mathrm{H}\} 13 C$ NMR $(151 \mathrm{MHz}, \mathrm{CD} 2 \mathrm{Cl} 2): \delta-0.9,55.2,102.7$ (d, JC-P= $6.4 \mathrm{~Hz}), 103.5,111.5(\mathrm{~d}, J C-P=5.1 \mathrm{~Hz})$, $120.5(d, J C-P=85.7 \mathrm{~Hz}), 121.1(\mathrm{~d}, J C-P=13.7 \mathrm{~Hz}), 125.2(\mathrm{~d}, J C-P=6.9 \mathrm{~Hz}), 127.7(\mathrm{~d}, J C-P=13.7 \mathrm{~Hz})$, $128.0(\mathrm{~d}, J C-P=13.7 \mathrm{~Hz}), 130.3(\mathrm{~d}, J C-P=2.1 \mathrm{~Hz}), 131.0(\mathrm{~d}, J C-P=3.0 \mathrm{~Hz}), 131.8(\mathrm{~d}, J C-P=12.0 \mathrm{~Hz})$, 132.5 (d, JC-P = 10.3 Hz), 133.2, 134.0 (d, JC-P = $1.9 \mathrm{~Hz}$ ), 134.8 (d, JC-P = 6.9 Hz), 135.4 (d, JC-P = 10.3 $\mathrm{Hz}), 136.0,160.3 ;\{1 \mathrm{H}\} 31 \mathrm{P}$ NMR $(243 \mathrm{MHz}, \mathrm{CD} 2 \mathrm{Cl} 2): \delta 40.5$ (s). HRMS calcd for $\mathrm{C} 24 \mathrm{H} 26 \mathrm{OPSSi}[\mathrm{M}+\mathrm{H}]+$ $\mathrm{m} / \mathrm{z}$ 421.12058, found $\mathrm{m} / \mathrm{z}$ 421.11908. Anal. Calcd for C24H25OPSSi: C, 68.54; H, 5.99. Found C, 68.40; $H, 6.32$.

(Sp)-o-Anisyl-[2-(ethynyl)phenyl]-phenylphosphine-sulfide (14): To a solution of compound 13 (0.430 $\mathrm{g}, 1.02 \mathrm{mmol})$ in a mixture of MeOH/THF (2:1) $(7.5 \mathrm{~mL})$ was added K2CO3 $(0.141 \mathrm{~g}, 1.02 \mathrm{mmol})$. The mixture was stirred at room temperature during two hours and the solvent was evaporated. Water (5 $\mathrm{mL}$ ) and $\mathrm{CH} 2 \mathrm{Cl} 2(15 \mathrm{~mL})$ were added and organic phase was separated then washed with water $(5 \mathrm{~mL})$ and finally dried over MgSO4. After filtration and evaporation of the solvent, the crude product was purified by column chromatography on silica gel using petroleum ether/ethyl acetate 3:1 as eluent to give compound 14 as a white solid $(0.345 \mathrm{~g}, 97 \%)$. $\mathrm{Rf} 0.39$ (petroleum ether/ethyl acetate 3:1); m.p. < $50^{\circ} \mathrm{C} ;[\alpha] \mathrm{D}+2.5(\mathrm{c} 0.3, \mathrm{CHCl} 3) .1 \mathrm{H} \mathrm{NMR}(600 \mathrm{MHz}, \mathrm{CD} 2 \mathrm{Cl} 2): \delta 2.95(\mathrm{~s}, 1 \mathrm{H}), 3.53(\mathrm{~s}, 3 \mathrm{H}), 6.95$ (dd, J = 5.5, 7.7 Hz, 1H), 7.16-7.18 $(\mathrm{m}, 1 \mathrm{H}), 7.38-7.41(\mathrm{~m}, 1 \mathrm{H}), 7.46-7.62(\mathrm{~m}, 7 \mathrm{H}), 8.03-8.07(\mathrm{~m}, 2 \mathrm{H}), 8.19(\mathrm{ddd}, \mathrm{J}=$ 1.7, 7.7, $17.1 \mathrm{~Hz}, 1 \mathrm{H}) ;\{1 \mathrm{H}\} 13 \mathrm{C} \mathrm{NMR}(151 \mathrm{MHz}, \mathrm{CD} 2 \mathrm{Cl} 2): \delta 55.2,81.3(\mathrm{~d}, \mathrm{JC}-\mathrm{P}=6.6 \mathrm{~Hz}), 85.0,111.3(\mathrm{~d}$, $J C-P=5.6 \mathrm{~Hz}), 120.3(\mathrm{~d}, J C-P=85.4 \mathrm{~Hz}), 121.0(\mathrm{~d}, J C-P=14.0 \mathrm{~Hz}), 123.8(\mathrm{~d}, J C-P=5.6 \mathrm{~Hz}), 127.8(\mathrm{~d}, J C-$ $P=12.9 \mathrm{~Hz}), 128.5(\mathrm{~d}, \mathrm{JC}-\mathrm{P}=11.8 \mathrm{~Hz}), 130.3(\mathrm{~d}, \mathrm{JC}-\mathrm{P}=2.4 \mathrm{~Hz}), 131.2(\mathrm{~d}, \mathrm{JC}-\mathrm{P}=3.5 \mathrm{~Hz}), 131.6(\mathrm{~d}, \mathrm{JC}-\mathrm{P}=$ $11.8 \mathrm{~Hz}$ ), 132.5 (d, JC-P = 89.4 Hz), 132.7 (d, JC-P = 11.8 Hz), 134.1 (d, JC-P = 2.4 Hz), 135.0 (d, JC-P = 9.4 $\mathrm{Hz}$ ), 135.5 (d, JC-P = 10.6 Hz), 136.7 (d, JC-P = 88.2 Hz), 160.4; \{1H\}31P NMR (243 MHz, CD2Cl2): $\delta 40.6$ (s). HRMS calcd for $\mathrm{C} 21 \mathrm{H} 180 \mathrm{OS}[\mathrm{M}+\mathrm{H}]+\mathrm{m} / \mathrm{z}$ 349.08105, found $\mathrm{m} / \mathrm{z}$ 349.08151. Anal. Calcd for C21H17OPS: C, 72.40; H, 4.92. Found C, 72.08; H, 5.07.

(Sp)-4-[2-(o-anisylphenylthiophosphinyl)phenyl]-1-phenyl-1H-1,2,3-triazole (15): To a solution of phosphine-alkyne $14(0.399 \mathrm{~g}, 1.15 \mathrm{mmol})$ in t-BuOH $(2 \mathrm{~mL})$ were successively added phenyl azide $(0.136 \mathrm{~g}, 1.15 \mathrm{mmol})$ then a solution of CuSO4.5H2O $(5.5 \mathrm{mg}, 0.034 \mathrm{mmol})$ ans sodium ascorbate (13.6 $\mathrm{mg}, 0.068 \mathrm{mmol})$ in water $(2 \mathrm{~mL})$. The resulting mixture was stirred at $40^{\circ} \mathrm{C}$ during 16 hours. After cooling to room temperature, a solution of $\mathrm{NH} 4 \mathrm{OH}$ ( $30 \%$ in water) $(2 \mathrm{~mL}$ ) was added followed by $5 \mathrm{~mL}$ of water. The mixture was extracted with methylene chloride $(3 \times 10 \mathrm{~mL})$ and the combined organic phases were dried over MgSO4. After filtration and evaporation of the solvent, the crude product was purified by column chromatography on silica gel using petroleum ether/ethyl acetate 1:1 as eluent to give the titled compound 15 as a pale yellow solid $(0.333 \mathrm{~g}, 62 \%)$. Rf 0.40 (petroleum ether/ethyl

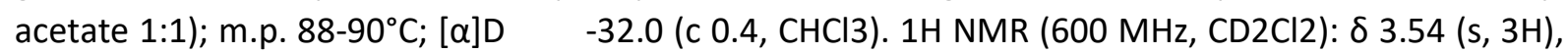
6.76 (br. t, J = 7.1 Hz, 1H), 6.98 (br. t, J = 7.1 Hz, 1H), 7.35-7.55 (m, 11H), $7.64(\mathrm{t}, \mathrm{J}=7.1 \mathrm{~Hz}, 1 \mathrm{H}), 7.87-$ $7.89(\mathrm{~m}, 1 \mathrm{H}), 8.06(\mathrm{dd}, \mathrm{J}=8.0,14.2 \mathrm{~Hz}, 2 \mathrm{H}), 8.37(\mathrm{dd}, \mathrm{J}=7.6,17.0 \mathrm{~Hz}, 1 \mathrm{H}), 8.92(\mathrm{~s}, 1 \mathrm{H}) ;\{1 \mathrm{H}\} 13 \mathrm{C} \mathrm{NMR}$ (151 MHz, CD2Cl2): $\delta$ 55.0, $111.2(d, J C-P=6.3 \mathrm{~Hz}), 119.3$ (d, JC-P = 83.5 Hz), 120.5, 120.7 (d, JC-P = $12.7 \mathrm{~Hz}$ ), 124.3, 127.7 (d, JC-P = 13.0 Hz), 127.9 (d, JC-P = 13.0 Hz), 128.4, 129.5, 130.8 (d, JC-P = 2.0 $\mathrm{Hz}), 131.2,131.2(\mathrm{~d}, J C-\mathrm{P}=15.0 \mathrm{~Hz}), 131.5(\mathrm{~d}, J C-\mathrm{P}=9.0 \mathrm{~Hz}), 132.1(\mathrm{~d}, \mathrm{JC}-\mathrm{P}=86.8 \mathrm{~Hz}), 132.5(\mathrm{~d}, \mathrm{JC}-\mathrm{P}=$ $12.0 \mathrm{~Hz}), 133.1(\mathrm{~d}, \mathrm{JC}-\mathrm{P}=8.0 \mathrm{~Hz}), 133.4,133.9(\mathrm{~d}, \mathrm{JC}-\mathrm{P}=2.0 \mathrm{~Hz}), 135.2(\mathrm{~d}, \mathrm{JC}-\mathrm{P}=9.0 \mathrm{~Hz}), 136.8,145.1$ (d, JC-P = 4.6 Hz), 159.4; \{1H\}31P NMR (243 MHz, CD2Cl2): $\delta 41.1$ (s). HRMS calcd for C27H22N3OPSNa 
[M+Na]+m/z 490.11134, found m/z 490.11154. Anal. Calcd for C27H22N3OPS: C, 69.36; H, 4.74. Found C, 69.02; H, 4.87 .

(Rp)-4-[2-(o-anisylphenylphosphinyl)phenyl]-1-phenyl-1H-1,2,3-triazole (8): To a solution of compound $15(0.31 \mathrm{~g}, 0.663 \mathrm{mmol})$ in toluene $(14 \mathrm{~mL})$ was added Si2Cl6 $(0.23 \mathrm{~mL}, 1.326 \mathrm{mmol})$. The resulting mixture was stirred under argon at $80^{\circ} \mathrm{C}$ during one hour. After cooling to $0{ }^{\circ} \mathrm{C}$, a solution of $\mathrm{NaOH}(30 \%$ in water) $(20 \mathrm{~mL})$ was added dropwise followed by water $(10 \mathrm{~mL})$ and methylene chloride $(20 \mathrm{~mL})$. The two phases were separated then aqueous phase was extracted with methylene chloride $(2 \times 20 \mathrm{~mL})$. The combined organic phases were dried over MgSO4, filtered and the solvent was evaporated. The crude product was purified by column chromatography on silica gel using petroleum ether/ethyl acetate $1: 1$ as eluent and recrystallization in hexane/CH2Cl2 to give the phosphine-triazole 8 as a white crystalline solid $(0.24 \mathrm{~g}, 83 \%)$. Rf 0.65 (petroleum ether/ethyl acetate $1: 1)$; m.p. $134-136^{\circ} \mathrm{C}$; Enantiomeric excess: $99 \%$ by HPLC analysis (Chiralpak IA, $1.0 \mathrm{~mL}$.min-1, hexane/2-propanol 90:10, tR (R) $32.6 \mathrm{~min}, \mathrm{tR}(\mathrm{S}) 35.2 \mathrm{~min})$; [ $\alpha] \mathrm{D}+49.0$ (c 0.3, $\mathrm{CHCl} 3)$. $1 \mathrm{H} \mathrm{NMR}(600 \mathrm{MHz}, \mathrm{CD} 2 \mathrm{Cl} 2): \delta 3.76(\mathrm{~s}, 3 \mathrm{H})$, 6.78-6.80 (m, 1H), $6.92(\mathrm{t}, \mathrm{J}=7.2 \mathrm{~Hz}, 1 \mathrm{H}), 6.98(\mathrm{dd}, \mathrm{J}=4.6,7.9 \mathrm{~Hz}, 1 \mathrm{H}), 7.07-7.09(\mathrm{~m}, 1 \mathrm{H}), 7.31-7.58(\mathrm{~m}$, $11 \mathrm{H}), 7.69(\mathrm{~d}, \mathrm{~J}=7.9 \mathrm{~Hz}, 2 \mathrm{H}), 8.05-8.07(\mathrm{~m}, 1 \mathrm{H}), 8.19(\mathrm{~s}, 1 \mathrm{H}) ;\{1 \mathrm{H}\} 13 \mathrm{C}$ NMR $(151 \mathrm{MHz}, \mathrm{CD} 2 \mathrm{Cl} 2): \delta 55.7$, $110.5,120.3,121.2,121.6(d, J C-P=17.8 \mathrm{~Hz}), 125.1$ (d, JC-P = $11.5 \mathrm{~Hz}), 128.2,128.5,128.7$ (d, JC-P = $7.6 \mathrm{~Hz}$ ), 128.8, 128.9, 129.6 (d, JC-P = 5.1 Hz), 129.7, 130.6, 134.0, 134.1, 134.2 (d, JC-P = 2.6 Hz), 135.2 $(d, J C-P=17.4 \mathrm{~Hz}), 135.5(d, J C-P=27.6 \mathrm{~Hz}), 136.4(d, J C-P=11.6 \mathrm{~Hz}), 137.1,146.7(d, J C-P=4.9 \mathrm{~Hz})$, $161.2(\mathrm{~d}, \mathrm{JC}-\mathrm{P}=14.1 \mathrm{~Hz}$ ); $\{1 \mathrm{H}\} 31 \mathrm{P}$ NMR $(243 \mathrm{MHz}, \mathrm{CD} 2 \mathrm{Cl} 2)$ : $\delta-22.4$ (s). HRMS calcd for C27H22N3OPNa $[\mathrm{M}+\mathrm{Na}]+\mathrm{m} / \mathrm{z}$ 458.13927, found $\mathrm{m} / \mathrm{z}$ 458.13979. Anal. Calcd for C27H22N3OP: C, 74.47; H, 5.09. Found C, 74.57; H, 4.99 .

Palladium complex (16): To a solution of phosphine-triazole $8(0.050 \mathrm{~g}, 0.115 \mathrm{mmol})$ and $[\mathrm{Pd}(\mathrm{n} 3-$ $\mathrm{C} 3 \mathrm{H} 5) \mathrm{Cl}] 2(0.019 \mathrm{~g}, 0.052 \mathrm{mmol})$ in methylene chloride $(1 \mathrm{~mL})$ was added a solution of AgPF6 (0.026 g, $0.104 \mathrm{mmol})$ in methanol $(0.3 \mathrm{~mL})$. The mixture was stirred at room temperature in the dark during one hour and the finely divided precipitate was filtered off using a Millipore $4 \mu \mathrm{m}$ filter. Slow addition of diethyl ether to the filtrate induced the formation of a powder which was filtered and washed with diethyl ether. Crystallization in $\mathrm{CH} 2 \mathrm{Cl} 2 / \mathrm{MeOH}$ gave the palladium complex 16 as a white crystalline solid (0.051 g, 68\%). M.p. 202-204 ${ }^{\circ} \mathrm{C}$; [ $\alpha$ ]D -27.8 (c 0.3, CHCl3). $1 \mathrm{H} \mathrm{NMR} \mathrm{(600} \mathrm{MHz,} \mathrm{CD2Cl2):} \delta 3.05$ (br.s, $1 \mathrm{H}), 3.28$ (br.s, $1 \mathrm{H}), 3.65(\mathrm{~s}, 3 \mathrm{H}), 3.89-3.92(\mathrm{~m}, 1 \mathrm{H}), 4.95$ (br.s, $1 \mathrm{H}), 5.79(\mathrm{t}, \mathrm{J}=8.2 \mathrm{~Hz}, 1 \mathrm{H}), 6.61-6.64(\mathrm{~m}$, $1 \mathrm{H})$, 6.86-6.89 $(\mathrm{m}, 1 \mathrm{H}), 6.95-6.98(\mathrm{~m}, 1 \mathrm{H})$, 7.04-7.07 $(\mathrm{m}, 1 \mathrm{H})$, 7.28-7.54 $(\mathrm{m}, 10 \mathrm{H}), 7.62-7.64(\mathrm{~m}, 1 \mathrm{H})$, 7.79-7.80 (m, 2H), 7.94-7.96 (m, 1H), $8.82(\mathrm{~s}, 1 \mathrm{H}) ;\{1 \mathrm{H}\} 13 \mathrm{C} \mathrm{NMR} \mathrm{(151} \mathrm{MHz,} \mathrm{CD2Cl2):} \delta 55.8,57.0,79.5$ (d, JC-P = 29.4 Hz), $111.5(d, J C-P=3.9 \mathrm{~Hz}), 116.5(d, J C-P=48.6 \mathrm{~Hz}), 120.8,121.5(\mathrm{~d}, J C-P=7.8 \mathrm{~Hz})$, 121.9 (d, JC-P = 5.8 Hz), 122.5, 123.3 (d, JC-P = 40.8 Hz), 128.1 (d, JC-P = 48.8 Hz), 129.3 (d, JC-P = 10.9 $\mathrm{Hz}$ ), 130.1, 130.3 (d, JC-P = 6.5 Hz), 130.5, 130.8 (d, JC-P = 8.7 Hz), 131.7 (d, JC-P = 2.2 Hz), 131.9 (d, JC$P=16.3 \mathrm{~Hz}), 132.5,133.4(\mathrm{~d}, J C-\mathrm{P}=4.3 \mathrm{~Hz}), 133.9(\mathrm{~d}, \mathrm{JC}-\mathrm{P}=8.7 \mathrm{~Hz}), 134.0,135.7,146.3$ (d, JC-P = 5.3 $\mathrm{Hz}$ ), 160.3 (d, JC-P = 7.0 Hz), one C missing; $\{1 \mathrm{H}\} 31 \mathrm{P} \mathrm{NMR} \mathrm{(243} \mathrm{MHz,CD2Cl2):} \delta 11.4$ (s), -144.4 (hept, $J F-P=710.5 \mathrm{~Hz}$ ). HRMS calcd for C30H27N3OPPd [M-PF6]+ m/z 582.09211, found $\mathrm{m} / \mathrm{z} 582.09182$.

Rhodium complex (17): A solution of phosphine-triazole $8(0.050 \mathrm{~g}, 0.115 \mathrm{mmol})$ in methylene chloride $(3.5 \mathrm{~mL})$ was slowly added to a suspension of [Rh(COD)2]BF4 $(0.045 \mathrm{~g}, 0.110 \mathrm{mmol})$ in methylene chloride $(2.5 \mathrm{~mL})$. The resulting mixture was stirred at room temperature during one hour then half of the solvent was removed under vacuum. Addition of diethyl ether induced the formation of an orange powder which was filtered, washed with diethyl elther and dried under vacuum. The rhodium complex was obtained as an orange solid (0.069 g, 81\%). M.p. $214-216^{\circ} \mathrm{C}$ (dec.). $1 \mathrm{H} \mathrm{NMR} \mathrm{(500} \mathrm{MHz,} \mathrm{CD2Cl2):} \delta$ 2.9-2.30 (m, 2H), 2.39-2.42 (m, 3H), 2.52-2.69 (m, 3H), 3.62 (br. s, 1H), 3.76 (br. s, $1 \mathrm{H}), 3.78(\mathrm{~s}, 3 \mathrm{H})$, 5.77-5.80 (m, $1 \mathrm{H}), 6.18-6.20(\mathrm{~m}, 1 \mathrm{H}), 7.01-7.10(\mathrm{~m}, 3 \mathrm{H})$, 7.42-7.53 $(\mathrm{m}, 5 \mathrm{H}), 7.60-7.78(\mathrm{~m}, 7 \mathrm{H}), 7.84-7.86$ $(\mathrm{m}, 2 \mathrm{H}), 7.92-7.93(\mathrm{~m}, 1 \mathrm{H}), 8.69(\mathrm{~s}, 1 \mathrm{H}) ;\{1 \mathrm{H}\} 13 \mathrm{C} \mathrm{NMR}(126 \mathrm{MHz}, \mathrm{CD} 2 \mathrm{Cl} 2): \delta 28.1,29.1,31.4,33.3,55.4$, 
79.5 (d, J = 11.9 Hz), 80.4 (d, J = 11.9 Hz), 105.4 (dd, J = 6.3, $10.0 \mathrm{~Hz}$ ), 107.2 (dd, J = 6.9, 9.0 Hz), 111.6 (d, JC-P = 3.5 Hz), 114.0 (d, JC-P = 48.3 Hz), 120.6, 121.4 (d, JC-P = 9.4 Hz), 122.6, 123.4 (d, JC-P = 43.5 $\mathrm{Hz}), 128.6(\mathrm{~d}, \mathrm{JC}-\mathrm{P}=47.5 \mathrm{~Hz}), 129.1(\mathrm{~d}, \mathrm{JC}-\mathrm{P}=11.1 \mathrm{~Hz}), 129.6(\mathrm{~d}, \mathrm{JC}-\mathrm{P}=7.1 \mathrm{~Hz}), 130.0,130.1,130.5$, $130.9(d, J C-P=16.6 \mathrm{~Hz}), 131.5(\mathrm{~d}, \mathrm{JC}-\mathrm{P}=2.4 \mathrm{~Hz}), 131.8,132.4,134.0,131.9(\mathrm{~d}, J C-\mathrm{P}=12.7 \mathrm{~Hz}), 135.6$ (d, JC-P = 8.7 Hz), 135.7, 160.3, two C missing; $\{1 \mathrm{H}\} 31 \mathrm{P}$ NMR $(203 \mathrm{MHz}, \mathrm{CD} 2 \mathrm{Cl} 2): \delta 23.4$ (d, JRh-P = $148.7 \mathrm{~Hz}$ ). HRMS calcd for C35H34N3OPRh [M-BF4]+ m/z 646.14890, found m/z 646.14781.

Procedure for asymmetric hydrogenation: A solution of [Rh(COD)8]BF4 (3.7 mg, $0.005 \mathrm{mmol}, 1 \mathrm{~mol} \%)$ and methyl $\alpha$-acetamidocinnamate $18(109.5 \mathrm{mg}, 0.5 \mathrm{mmol})$ in dry methanol $(7.5 \mathrm{~mL})$ was introduced in a stainless steel autoclave. The autoclave was closed, purged with hydrogen and then pressurized with 10 bar of hydrogen. After $16 \mathrm{~h}$ of stirring at room temperature, the pressure was released to atmospheric pressure and the solution was transferred to a round bottom flask. The solvent was removed to give a residue, which was purified by column chromatography on silica gel to afford the hydrogenated product 19. Enantiomeric excess was determined by HPLC analysis (Chiralcel OD-H, 1 mL.min-1, hexane/2-propanol 95:5, tR (R) $21.4 \mathrm{~min}$, tR (S) $34.7 \mathrm{~min}$ ). 1H NMR (500 MHz, CDCl3): $\delta 1.97$ $(\mathrm{s}, 3 \mathrm{H}), 3.06-3.07(\mathrm{~m}, 2 \mathrm{H}), 3.64(\mathrm{~s}, 3 \mathrm{H}), 4.85-4.87(\mathrm{~m}, 1 \mathrm{H}), 6.11$ (br. $\mathrm{s}, 1 \mathrm{H}), 7.18-7.20(\mathrm{~m}, 5 \mathrm{H})$.

Procedure for asymmetric allylic alkylation: A solution of $[\mathrm{Pd}(\mathrm{n} 3-\mathrm{C} 3 \mathrm{H} 5) \mathrm{Cl}] 2(3.6 \mathrm{mg}, 0.010 \mathrm{mmol})$, phosphine-triazole $8(8.8 \mathrm{mg}, 0.020 \mathrm{mmol}$ ) and (E)-1,3-diphenylprop-2-en-1-yl acetate $20(126 \mathrm{mg}, 0.5$ $\mathrm{mmol})$ in $2 \mathrm{~mL}$ of toluene was stirred one hour at room temperature. Dimethylmalonate $(0.12 \mathrm{~mL}, 1.0$ $\mathrm{mmol})$ was added followed by BSA $(0.24 \mathrm{~mL}, 1.0 \mathrm{mmol})$ and KOAc $(5.0 \mathrm{mg}, 0.05 \mathrm{mmol})$. The reaction was stirred at room temperature during 5 hours (full conversion). The reaction mixture was diluted with $\mathrm{Et} 2 \mathrm{O}$ and saturated aqueous $\mathrm{NH} 4 \mathrm{Cl}$ solution was added. The mixture was extracted with Et2O, and the organic phases were dried over MgSO4. After filtration, the solvent was removed to give a residue, which was purified by column chromatography on silica gel to afford the product 21 . Enantiomeric excess was determined by HPLC analysis (Chiralpak IA, $1 \mathrm{~mL}$.min-1, hexane/2-propanol 90:10, tR (R) $8.5 \mathrm{~min}, \mathrm{tR}(\mathrm{S}) 10.4 \mathrm{~min}) .1 \mathrm{H} \mathrm{NMR} \mathrm{(500} \mathrm{MHz,} \mathrm{CDCl3):} \delta 3.56(\mathrm{~s}, 3 \mathrm{H}), 3.75(\mathrm{~s}, 3 \mathrm{H}), 4.02$ (d, J $=10.9 \mathrm{~Hz}, 1 \mathrm{H}), 4.27(\mathrm{dd}, \mathrm{J}=8.8,10.8 \mathrm{~Hz}, 1 \mathrm{H}), 6.40(\mathrm{dd}, \mathrm{J}=8.6,15.7 \mathrm{~Hz}, 1 \mathrm{H}), 6.54(\mathrm{~d}, \mathrm{~J}=15.7 \mathrm{~Hz}, 1 \mathrm{H})$, 7.10-7.40 (m, 10H).

\section{Acknowledgments}

The authors are grateful for the financial support provided by the CNRS, Ministère de l'Education Nationale et de la Recherche, Université de Bourgogne, Conseil Régional de Bourgogne through the Plan d'Actions Régional pour I'Innovation (PARI) and the Fonds Européen de Développement Régional (FEDER) programs. It is also a pleasure to thank M. J. Penouilh and M. Picquet at the Sayens/Pôle Chimie Moléculaire for the NMR and mass spectrometry analyses, and M. J. Eymin for her skilled technical assistance.

Keywords: P-Chirogenic phosphine • Stereoselective synthesis• Coordination chemistry • Transition metals • Asymmetric catalysis

[1] a) Y. Zhao, M. G. Wakeling, F. Meloni, T. J. Sum, H. van Nguyen, B. R. Buckley, P.W. Davies, J. S. Fossey, Eur. J. Org. Chem. 2019, 5540-5548; b) Y. Zhao, M. G. Wakeling, F. Meloni, T. J. Sum, H. van Nguyen, B. R. Buckley, P.W. Davies, J. S. Fossey, ChemRxiv 2019, 1-17; c) T. P. Seifert, S. Bestgen, T. J. Feuerstein, S. Lebedkin, F. Krämer, C. Fengler, M. T. Gamer, M. M. Kappes, P. W. Roesky, Dalton Trans. 2019, 48, 15427-15434; d) Y. Zhao, H. van Nguyen, L. Male, P. Craven, B. R. Buckley, J. S. Fossey, Organometallics 2018, 37, 4224-4241; e) L Cao, S. Huang, W. Liu, X. Yan, Organometallics 2018, 37, 2010-2013; f) Y. Zhao, H. van Nguyen, L. Male, P. Craven, B. R. Buckley, J. S. Fossey, ChemRxiv 2018, 130; g) C. Zeng, N. Wang, T. Peng, S. Wang, Inorg. Chem. 2017, 56, 1616-1625; h) R. Veillard, E. Bernoud, I. Abdellah, J.-F. Lohier, C. Alayrac, A.-C. Gaumont, Org. Biomol. Chem. 2014, 12, 3635-3640; i) N. V. 
Dubrovina, L. Domke, I. A. Shuklov, A. Spannenberg, R. Franke, A. Villinger, A. Börner, Tetrahedron 2013, 69, 8809-8817; j) J. E. Glover, D. J. Martin, P. G. Plieger, G. J. Rowlands, Eur. J. Org. Chem. 2013, 1671-1675; k) M. Austeri, M. Enders, M. Nieger, S. Bräse, Eur. J. Org. Chem. 2013, 1667-1670; I) T. Konno, K. Shimizu, K. Ogata, S.-i. Fukuzawa, J. Org. Chem. 2012, 77, 3318-3324; m) E. A. Slutsky Smith, G. Molev, M. Botoshansky, M. Gandelman, Chem. Commun. 2011, 47, 319-321; n) Y. Matano, M. Nakashima, A. Saito, H. Imahori, Org. Lett. 2009, 11, 3338-3341; o) R. J. Detz, S. Arévalo Heras, R. de Gelder, P. W. N. M. van Leeuwen, H. Hiemstra, J. N. H. Reek, J. H. van Maarseveen, Org. Lett. 2006, 8, 3227-3230; p) S. Trofimenko, A. L. Rheingold, C. D. Incarvito, Angew. Chem. Int. Ed. 2003, 42, 35063509.

[2] a) D. Liu, W. Gao, Q. Dai, X. Zhang, Org. Lett. 2005, 7, 4907-4910; b) Q. Dai, W. Gao, D. Liu, L. M. Kapes, X. Zhang, J. Org. Chem. 2006, 71, 3928-3934.

[3] a) D. M. Zink, T. Grab, T. Baumann, M. Nieger, E. C. Barnes, W. Koppler, S. Bräse, Organometallics 2011, 30, 3275-3283; b) D. M. Zink, T. Baumann, M. Nieger, S. Bräse, Eur. J. Org. Chem. 2011, 1432-1437.

[4] C. Laborde, M.-M. Wei, A. van der Lee, E. Deydier, J.-C. Daran, J.-N. Volle, R. Poli, J.-L. Pirat, E. Manoury, D. Virieux, Dalton Trans. 2015, 44, 12539-12545.

[5] a) S.-i. Fukuzawa, H. Oki, M. Hosaka, J. Sugazawa, S. Kikuchi, Org. Lett. 2007, 9, 5557-5560; b) S.-i. Fukuzawa, H. Oki, Org. Lett. 2008, 10, 1747-1750; c) H. Oki, I. Oura, T. Nakamura, K. Ogata, S.-i. Fukuzawa, Tetrahedron: Asymmetry 2009, 20, 2185-2191.

[6] a) E. M. Schuster, M. Botoshansky, M. Gandelman, Angew. Chem. Int. Ed. 2008, 47, 4555-4558; b) E. M. Schuster, M. Botoshansky, M. Gandelman, Organometallics 2009, 28, 7001-7005; c) E. M. Schuster, G. Nisnevich, M. Botoshansky, M. Gandelman, Organometallics 2009, 28, 5025-5031.

[7] F. Dolhem, M. J. Johansson, T. Antonsson, N. Kann, J. Comb. Chem. 2007, 9, 477-486.

[8] a) B. Choubey, L. Radhakrishna, J. T. Mague, M. S. Balakrishna, Inorg. Chem. 2016, 55, 85148526. b) L. Radhakrishna, M. K. Pandey, M. S. Balakrishna, RSC. Adv. 2018, 8, 25704. c) L. Radhakrishna, H. S. Kunchur, P. K. Namdeo, R. J. Butcher, M. S. Balakrishna, Dalton Trans. 2020, 49, 3434-3449.

[9] J. D. Crowley, D. A. McMorran, Top Heterocyl. Chem. 2012, 28, 31-84.

[10] Fukuzawa and Kann reported, respectively, the use of a planar chiral and P-chirogenic triazolebased $\mathrm{P}, \mathrm{N}$ ligand in $\mathrm{Pd}$-catalyzed asymmetric allylic alkylation (see ref $5 \mathrm{~b}$ and 7 ) but no study of its coordination mode toward Pd was reported.

[11] a) J. Bayardon, H. Lauréano, V. Diemer, M. Dutartre, U. Das, Y. Rousselin, J.-C. Henry, F. Colobert, F. R. Leroux, S. Jugé, J. Org. Chem. 2012, 77, 5759-5769; b) E. Rémond, J. Bayardon, S. Takizawa, Y. Rousselin, H. Sasai, S. Jugé, Org. Lett. 2013, 15, 1870-1873; c) J. Bayardon, J. Bernard, E. Rémond, Y. Rousselin, R. Malacea-Kabbara, S. Jugé, Org. Lett. 2015, 17, 1216-1219; d) J. Bayardon, S. Jugé, Phosphorus, Sulfur, and Silicon 2015, 190, 700-705; e) J. Bayardon, M. Maronnat, A. Langlois, Y. Rousselin, P. D. Harvey, S. Jugé, Organometallics 2015, 34, 4340-4358; f) J. Bayardon, Y. Rousselin, S. Jugé, Org. Lett. 2016, 18, 2930-2933.

[12] F. Chaux, S. Frynas, H. Lauréano, C. Salomon, G. Morata, M.-L. Auclair, M. Stephan, R. Merdès, P. Richard, M.-J. Ondel-Eymin, J.-C. Henry, J. Bayardon, C. Darcel, S. Jugé, C. R. Chim. 2010, 12, 12131226. 
[13] o-anisyllithium was prepared by metal-halide exchange from 2-bromoanisole, using secbutyllithium, as reported in ref 12 .

[14] C. Bauduin, D. Moulin, E. B. Kaloun, C. Darcel, S. Jugé, J. Org. Chem. 2003, 68, 4293-4301.

[15] Y. Xu, Z. Wang, Z. Gan, Q. Xi, Z. Duan, F. Mathey, Org. Lett. 2015, 17, 1732-1734.

[16] Partial decomplexation of sterically hindered phosphine borane has been already observed in our group (see ref 11a and 14).

[17] V. V. Rostotsev, L. G. Green, V. V. Fokin, K. B. Sharpless, Angew. Chem. Int. Ed. 2002, 41, 25962599.

[18] G. Zon, K. E. DeBruin, K. Naumann, K. Mislow, J. Am. Chem. Soc. 1969, 91, 7023-7027.

[19] The RP configuration of phosphine-triazole 8 as well as the configuration of the P-center of each intermediate 10,12,13,14 and 15 are in good agreement with the stereochemistry previously reported for the ephedrine methodology (see for example ref 14 ) and for the desulfidation with $\mathrm{Si2} 2 \mathrm{Cl} 6$ (see ref 18).

[20] Shifting of the triazole methine-proton in palladium complexes indicates a bidentate $P, N$ coordination mode, see ref $1 \mathrm{n}$ and 10 .

[21] In some cases, $15 \mathrm{~N} \mathrm{NMR} \mathrm{chemical} \mathrm{shift} \mathrm{of} \mathrm{N-2} \mathrm{central} \mathrm{atom} \mathrm{on} \mathrm{the} \mathrm{triazole} \mathrm{ring} \mathrm{was} \mathrm{not}$ determined. See for example: A. Bolje, D. Urankar, J. Kosmrlj, Eur. J. Org. Chem. 2014, 8167-8181.

[22] Similar coordination shifts of $15 \mathrm{~N}$ resonances were already reported for nitrogen containing ligand and palladium and rhodium complexes. See for example: a) V. Rosar, D. Dedeic, T. Nobile, F. Fini, G. Balducci, E. Alessio, C. Carfagna, B. Milani, Dalton Trans. 2016, 45, 14609-14619; b) M. Teresa Pereira, J. M. Antelo, L. A. Adrio, J. Martinez, J. M. Ortigueira, M. Lopez-torres, J. M. Vila, Organometallics 2014, 33, 3265-3274; c) A. Satake, H. Koshino, T. Nakata, J. Organomet. Chem. 2000, 595, 208-214; d) E. Szlyk, A. Grodzicki, L. Pazderski, A. Wojtczak, J. Chatlas, G. Wrzeszcz, J. Sitkowski, B. Kamienski, J. Chem. Soc., Dalton Trans. 2000, 867-872.

[23] D. Cremer, J. A. Pople, J. Am. Chem. Soc. 1975, 97, 1354-1358.

[24] a) M. Kollmar, B. Goldfuss, M. Reggelin, F. Rominger, G. Helmchen, Chem. A Eur. J. 2001, 7, 4913-4927; b) L. B. Schenkel, J. A. Ellman, Org. Lett. 2003, 5, 545-548; c) N. Baltzer, L. Macko, S. Schaffner, M. Zehnder, Helv. Chim. Acta 1996, 79, 803-812.

[25] Similar coupling constant was already observed for triazole-phosphine rhodium complex (see ref $8 c)$.

[26] For reviews of $\mathrm{P}, \mathrm{N}$-ligands in $\mathrm{Rh}$ - and $\mathrm{Pd}$-catalyzed asymmetric reactions, see: a) B. V. Rokade, P. J. Guiry, ACS Catal. 2018, 8, 624-643; b) I. D. Kostas, Curr. Org. Chem. 2008, 5, 227-249; c) P. J. Guiry, C. P. Saunders, Adv. Synth. Catal. 2004, 346, 497-537; d) G. Chelucci, G. Orrù, G. A. Pinna, Tetrahedron 2003, 59, 9471-9515; e) K. N. Gavrilov, A. I. Polosukhin, Russ. Chem. Rev. 2000, 69, 661-682; f) G. Helmchen, A. Pfaltz, Acc. Chem. Res. 2000, 33, 336-345.

[27] E. B. Kaloun, R. Merdès, J.-P. Genêt, J. Uziel, S. Jugé, J. Organomet. Chem. 1997, 529, 455-463.

[28] M. I. Mangione, R. A. Spanevello, M. B. Anzardi, RSC Adv. 2017, 7, 47681-47688. 


\section{FULL PAPER}

The stereoselective synthesis of a novel P-chirogenic triazole-based phosphine was achieved. Its coordination to transition-metals was explored, and a $\mathrm{P}, \mathrm{N}$-chelation mode was demonstrated. Application to this chiral phosphine as ligand in asymmetric catalysis is also reported.

P-Chirogenic Phosphine*

Jérôme Bayardon, * Benjamin Rousselle, Yoann Rousselin, Quentin Bonnin, Raluca Malacea-Kabbara* Page No. - Page No.

P-chirogenic triazole-based phosphine: synthesis, coordination chemistry and asymmetric catalysis 